\title{
Geological and geotechnical evaluation for the stabilization of tail race tunnel outfall slope - a case study of tehri pump storage plant (I000 MW), tehri garhwal (Uttarakhand)
}

\begin{abstract}
Tehri project, a prestigious hydropower project is the first major attempt to harness vast hydro potential of bhagirathi river which is fed by gangotri glacier. The storage project in the bhagirathi valley in uttarakhand himalaya, envisages impounding of surplus monsoon water of the river for utilizing it in regulated manner for hydropower generation. The $2400 \mathrm{mw}$ tehri hydro power complex comprises of tehri hydropower project(hpp)) (1000mw) stage-1,koteshwar hydroelectric project(400mw) and tehri pumped storage plant (psp) $(1000 \mathrm{mw})$. Tehri pumped storage plant(psp) is being under construction and aligned parallel in the same hill as the tehri hpp underground complex. Major project components under construction are machine hall, upstream surge shafts, butterfly valve chamber, penstock assemble chamber, downstream surge shafts, pair of tail race tunnel and outlet structure. The two tail race tunnel namely trt-3 (1081 m long) $\&$ trt-4(1174 m long) are connected to outfall/intake structure with sluice gate and trash rack. This outfall structure is an integral part of the tehri pump storage plant and is of utmost importance. To accommodate the hydro mechanical and electro mechanical components at outlet structure, safe cut slope is require based on rock type and geotechnical parameters to ensure safety of the outfall structure. Detailed geological/ geotechnical investigations were carried out and suitable methodology for the slope stabilization adopted in different variant of phyllitic rock and patch of $\mathrm{rbm} / \mathrm{dumped}$ material, which is emerged as a geological surprise. This paper briefly describes the construction methodology for trt outfall structure giving excavation sequence, slope stabilization and strengthening of slope based on geological and geotechnical data obtained from the investigation and monitoring instruments installed at the structure.

Keywords: geological/geotechnical investigation, excavation sequence, slope stabilization, strengthening of slope, rock mass, recycling the water, penstock assemble chamber, geological mapping, core drilling, chandpur phyllites, lithological variants, outfall area, rock stratigraphy, lithological variants
\end{abstract}

Volume 2 Issue 5 - 2018

\author{
Nishith sharma, Rajeev Prasad
}

Hindustan Construction Company, India

\begin{abstract}
Correspondence: Rajeev Prasad, Chief Geologist, Tehri Pump Storage with Hindustan Construction Company, Kandkhala, Tehri Garhwal, India, 249|30,Tel+9|8192899283,
\end{abstract} +918476000267, Email rpendia@hotmail.com

Received: September 24, 2018 | Published: December 31 , 2018

\section{Introduction}

Tehri pump storage plant is located in the left bank of river bhagirathi in the state of uttarakhand falling between $78^{\circ} 30^{\prime}$ and $79^{\circ} 00^{\prime}$ e longitudes and corresponding $30^{\circ} 30^{\prime}$ and $33^{\circ} 30^{\prime} \mathrm{n}$ latitudes (Figure 1). The nearest rail head is rishikesh which is located approximately $82 \mathrm{~km}$ from project site. ${ }^{1}$ It will be a peaking power plant located between the tehri and koteshwar dam, which is also the part of tehri hydro power complex. Tehri pump storage plant is being developed by thdc india limited (a joint venture of central government of india and government of uttar pradesh). ${ }^{2}$ Tehri dam forms as an upper reservoir while koteshwar dam will serve as a lower reservoir to the tehri pump storage plant. Power will be generated by recycling the water discharge between two reservoirs. Tehri pump storage plant which is under construction and being executed by $\mathrm{m} / \mathrm{s}$ Hindustan Construction Company under epc mode. The major project components are machine hall, upstream and downstream shafts, butterfly valve chamber, penstock assemble chamber, a pair of tail race tunnel and outlet structure. Tail race tunnel outfall structure is not like a usual outfall structures, but a very critical one as this structure also has to work as an intake. Design and construction of this structure involves some key issues, such as stability of outfall slope, geotechnical parameters of the rock mass and support estimation. In view of these issues detailed surface geological mapping, core drilling at various locations suggested by designers as well as exploratory cross cut drifts $(\mathrm{ea}-08)^{3}$ has been excavated to explore the subsurface geological conditions behind the slope. Based on all above information geological model of slope has been developed. To support the findings a geological plant and sections have been developed using geological information of ea- 08 and core logs drilled at various locations in trt outfall area. ${ }^{4}$ In addition to this geotechnical parameters such as ucs and gsi have also been taken using schmidt hammer readings and geological strength index chart ${ }^{5}$ after carried out detailed geological/ geotechnical investigations, a methodology was chalk out to strengthened the outfall slope with detail excavation sequence using geological/geotechnical data obtained from monitoring instruments installed at site described briefly in this paper. The typical excavation plan of trt outfall /intake and natural slope are shown in Figure $2 \&$ Figure 3 .

\section{A. Regional geological set up}

Tehri project area lies within the main himalayan block (mhb), in the midlands of lesser himalayas bounded to north and south by regional tectonic lineaments - the main central thrust (mct) and main boundary fault (mbf) respectively. The former, to the north separates the meta-sedimentary sequence of lesser himalayas from the 
crystalline rocks of higher himalayas and the latter marks boundary between lesser himalaya and tertiary sequence of frontal foothill belt (ffb), in the south. The rock stratigraphy of lesser himalaya exposed around the tehri project area are broadly classified in to garhwal, shimla, jaunsar, karol and tal groups, ${ }^{2}$ the folded metasedimentary rocks exposed around the project site form an uninterrupted sequence of chandpur phyllites having variable propotion of argillaceous and arenaceous constituents. Considering the rythmicity of intercalated bands and varied degree of tectonic effects in them, the phyllites has been classified in to mainly four lithological variants. Rock mass in this area are mainly variants of phyllites and classified as below:

i. Phyllitic Quartzite Massive(PQM)

ii. Phyllitic Quartzite Thinly Bedded(PQT)

iii. Sheared Phyllite/Schistose Phyllite(SP)

Pqm and pqt are more quartzitic (arenaceous) and rarely micaceous in composition with coarser grain size. These rocks are grey, dark grey, greenish and grayish grey in colour. It is mainly comprises of quartz, feldspar and oriented leths of micaceous minerals.qp is more arenoargillaceous in composition. Sp comprises of argillaceous and deformed variants of pqm and pqt rock formed in shear zone area which has weak rock mass characteristics. ${ }^{7}$

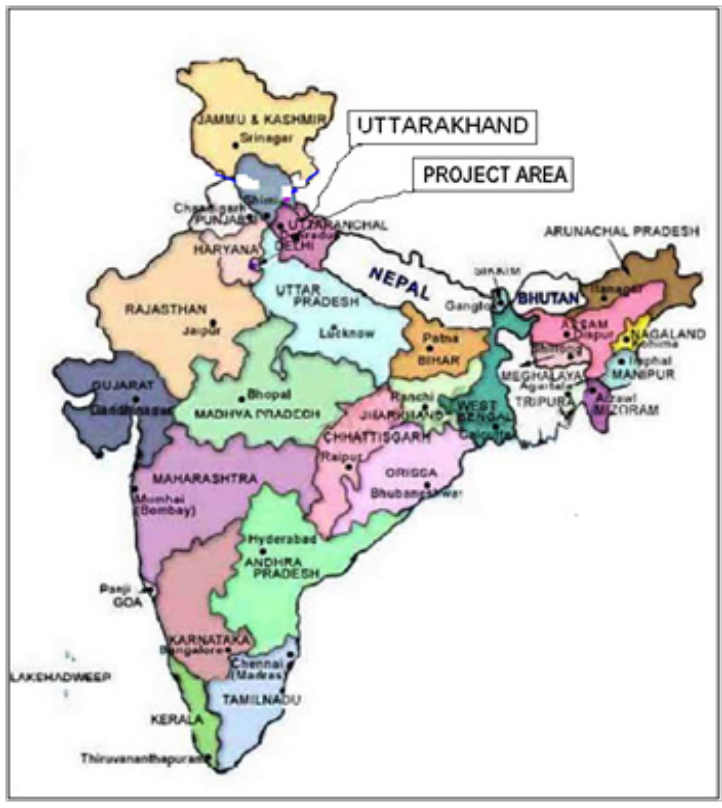

Figure I Showing the location map of Project area

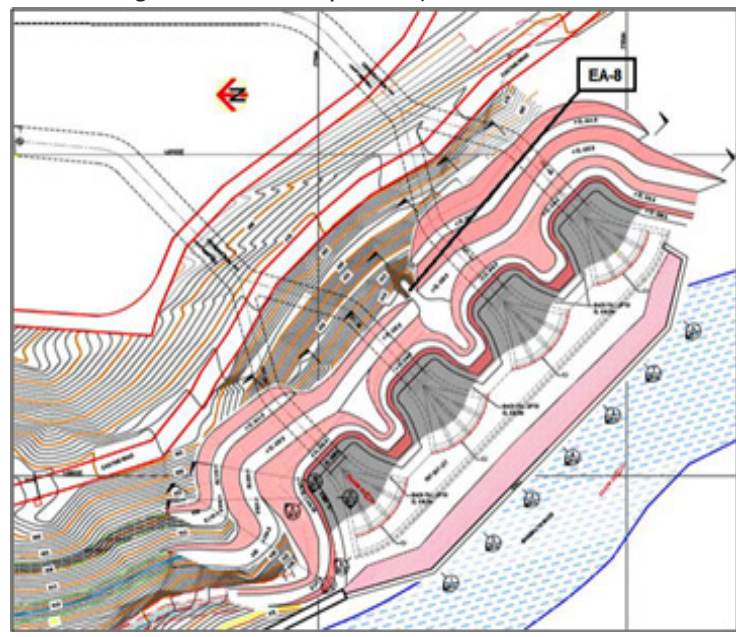

Figure 2 Plan view of TRT outfall cut slopes

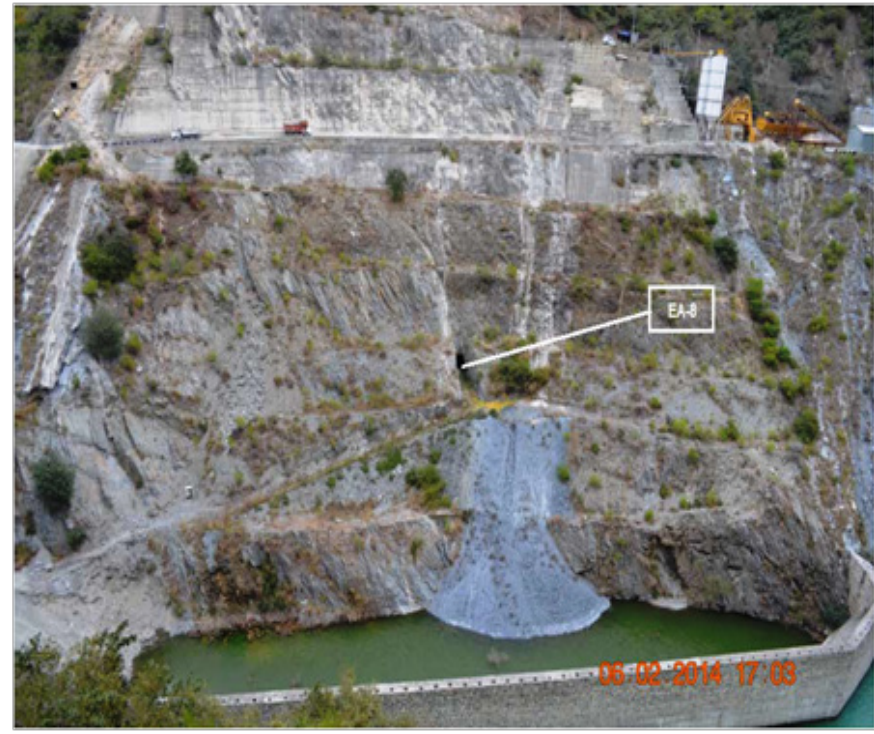

Figure 3 TRT outfall natural slopes (i.e before excavation)

Table I Discontinuity data of the TRT Outfall Slope

\begin{tabular}{|c|c|c|c|c|c|}
\hline $\begin{array}{l}\text { Joint } \\
\text { Set }\end{array}$ & $\begin{array}{l}\text { Avg. Dip } \\
\text { Amount }\end{array}$ & $\begin{array}{l}\text { Average } \\
\text { Dip } \\
\text { Direction }\end{array}$ & $\begin{array}{l}\text { Spacing } \\
(\mathrm{Cm})\end{array}$ & Filling & Roughness \\
\hline Jl & $\begin{array}{l}\mathrm{N} 180^{\circ}- \\
210^{\circ}\end{array}$ & $45^{\circ}-55^{\circ}$ & Oct-40 & $\begin{array}{l}\text { Clay \& } \\
\text { Crushed } \\
\text { Rock }\end{array}$ & $\begin{array}{l}\text { Undulation } \\
\text {, Slightly } \\
\text { Rough }\end{array}$ \\
\hline $\mathrm{J} 2$ & $\begin{array}{l}\mathrm{N} 140^{\circ}- \\
165^{\circ}\end{array}$ & $35^{\circ}-45^{\circ}$ & $25-60$ & $\begin{array}{l}\text { Crushed } \\
\text { Rock } \\
\text { with } \\
\text { Quartz }\end{array}$ & $\begin{array}{l}\text { Planner, } \\
\text { Slightly } \\
\text { Rough }\end{array}$ \\
\hline
\end{tabular}

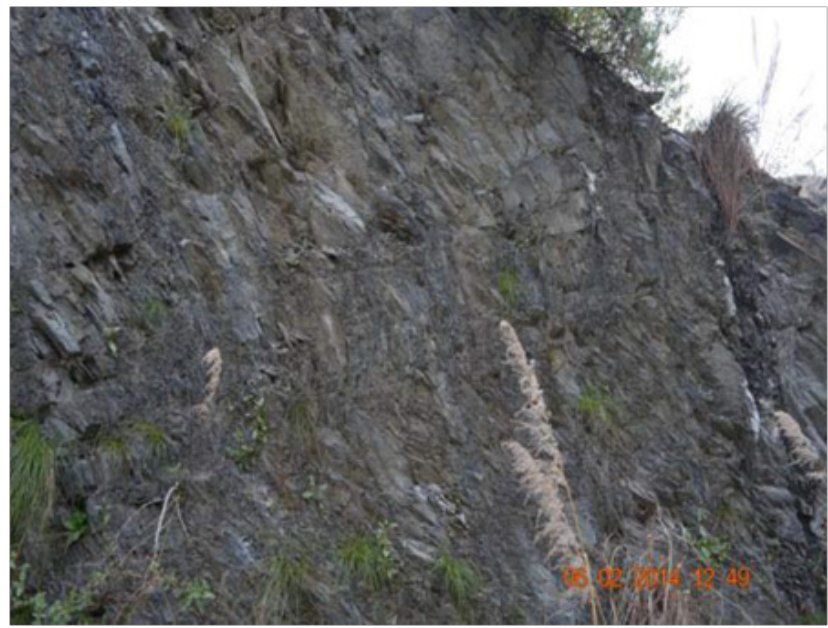

Figure 4 Kink Bands in SP occupied Zone

\section{B. Site specific geology}

Trt outfall slope is characterized by the presence of pqm+pqt, qp with bands of pqt and sp. Pqm and pqt are the massive varieties with different bed thickness while sp occupies very weak and sheared phyllite zone. In general thickness varies from few $\mathrm{cm}$. To $1.50 \mathrm{~m}$ as observed in exploratory drift. Surface geological mapping indicates that the rocks of pqt+pqm are well exposed in the rocky cliff just upstream of trt-3 portal i.e. Near the upstream of coffer dam and extended up to exploratory drift(ea-08) portal. In general the strata is uniformly dipping with kinking particularly in sp occupied stretches and dips at $\mathrm{n} 195^{\circ} / 45^{\circ}-55^{\circ}(\mathrm{j} 1$ set of joint $)$ and are dissected by joint

Citation: Sharma N, Prasad R. Geological and Geotechnical Evaluation for the Stabilization of Tail Race Tunnel Outfall Slope - A case study of Tehri Pump Storage Plant (I000 MW), Tehri Garhwal (Uttarakhand). Fluid Mech Res Int J. 20I8;2(5):234-24I. DOI: I0.15406/fmrij.20I8.02.00043 
set j2:n150 $/ 35^{\circ}-45^{\circ}, \mathrm{j} 3: n 20^{\circ} / 60^{\circ}-65^{\circ}$ and j4:n295\% $60^{\circ}-70^{\circ}$ other than the foliation joint $\mathrm{j} 1$. This foliation joint is represented by smooth and slightly undulating surfaces. Very closely to closely spaced and have persistence and have persistence along strike of $3-10 \mathrm{~m}$ joint sets $\mathrm{j} 2$ and $\mathrm{j} 3$ are slightly rough, planar to slightly undulating, closely to widely spaced and have a persistence of generally $<10 \mathrm{~m}$ joint set $\mathrm{j} 4$ is rough, planar and discontinuous with persistence of $<3$ to $4 \mathrm{~m}$ details of discontinuity data observed in trt outfall area mentioned in Table 1. On the nw side of the cutting several shear bands within the phyllites are exposed and these can be traced $20-30 \mathrm{~m}$ along the slope, but appear to not extend as far as the ea-08 portal area. These shear zones are the major cause of planar/polygonal failure as they are dipping along the direction of cut slope. Some kink bands have been observed in the upstream part of slope which can also the cause of failure along with other joints as shown in Figure 4. Overburden observed just downstream of trt-4 portal and also towards upstream of trt-3 portal comprises the colluviums limit of rock exposure. The thickness of overburden increases at higher reaches, however in general it has been expected less then 3.0meters in both directions. The present slope is moderately inclined; dipping towards sw direction i.e. N225 ${ }^{\circ}$. Overall this slope is concave in disposition and the slope is sub-parallel to strike of foliation towards upstream (near ridge i.e. $30-40 \mathrm{~m}$ upstream of ea- 08 portal) and is oblique at an angle of $40^{\circ}-45^{\circ}$ towards downstream (Figure 5)

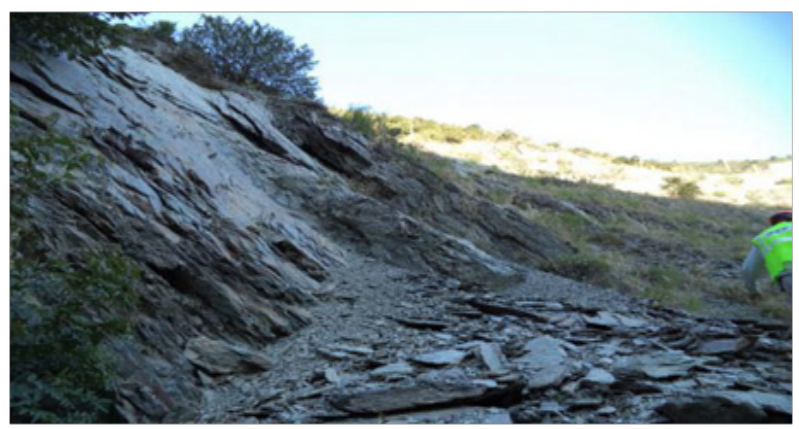

Figure 5 Dip slope about 30-40m upstream of EA-08 portal

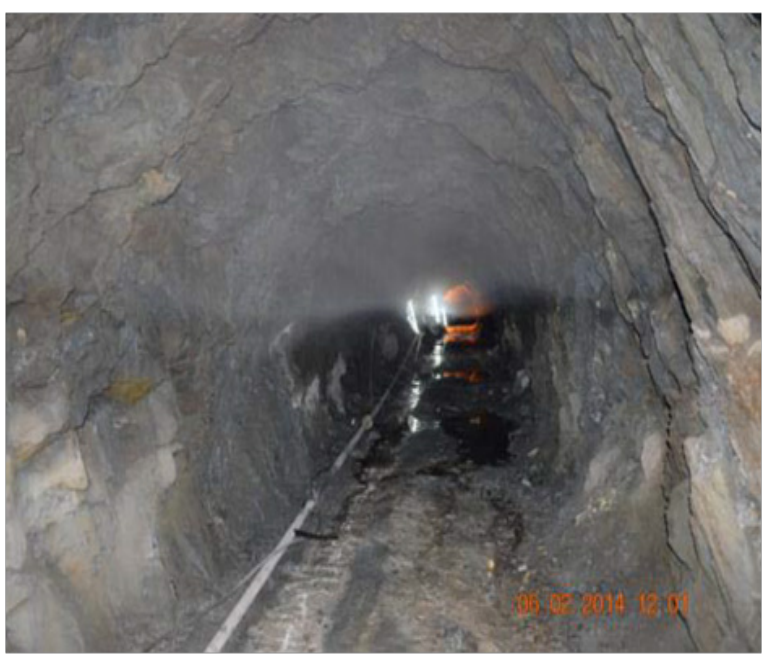

Figure 6 Encountered Rock mass during drifting of EA-08

\section{Geotechnical investigation}

i. Geology along exploratory drift (ea-08)

ii. Exploratory drift, $2.60 \mathrm{~m}$ diameter and $151.0 \mathrm{~m}$ in length with cross cut at rd:-70.0m was excavated to explore the subsurface geological condition behind the slope. Rock is well exposed throughout the excavated length of tunnel and gives a very good section with varying in lithology (Figure 6), detail of rock type encountered during drifting representing geological mapping with trends of attitude is shown in Figure 7, sp is initially encountered up to $5-7 \mathrm{~m}$ followed by pqt+ pqm.sp has shearing effects give rise to kink bands. Shear zones are oriented along foliation and having the swelling/pinching in nature. Wet to damp ground water condition observed throughout the drift except one or two location where dripping observed. The rock mass is slightly weathered up to rd:-25.0m where iron staining has been noticed along joint planes particularly in pqt+pqm occupied zones. In the rest portion of drift rock mass has been found to be fresh and devoid of any discoloration. Apart from shear zones encountered, the joints have been found to be tight. No kinking and buckling effects have been found in drift except the sp occupied reach which is the characteristics feature of it.

\section{iii. Exploratory holes}

Core drilling was carried out at various locations of trt outfall area to study the subsurface conditions and behavior of rock mass. Total 06 nos, of core holes were drilled as mentioned in Table $1 \&$ Table 2.

Based on all above information geological model of the slope have been developed using surface geological map and core hole data to know the behavior of rock mass. Geological sections at various locations in trt outfall area indicates the contact between $\mathrm{rbm} / \mathrm{talus}$ ,swelling and pinching of shear zone, litho unit as well as weathering limit (Figure 8).

\section{iv. Computation of geotechnical parameters}

Geotechnical parameter such as unconfined compressive strength (ucs) and geological strength index (gsi) plays an important role for the designing of any structure.ucs is generally estimated from test carried out on intact rock core pieces in laboratory. An alternative method is by using rebound or schmidt hammer to measure the ucs in field. Keeping view of uncertainties in testing readings was taken in all three directions w.r.t. Foliation in ea-08. It has been observed that the ucs values were very high in pqm, pqt, qp and low for sp bands. Analysis of these schmidt hammer rebound values shows that there is a big variation in ucs.the reading taken perpendicular to foliation was very high comparison to those taken along foliation. Hence values perpendicular to foliation plane are considered ${ }^{8}$, as the drift is moist throughout in excavated length so ucs values recommended for saturated conditions. The ucs values estimated for the major litho units and averaging of same is recommended for design purpose as shown in Table 3. The geological strength index(gsi) is very useful in modeling and can be obtained from rmr' or directly by gsi chart. ${ }^{5}$ This procedure works in good quality of rock mass and it is meaningless in the range of poor rock mass, therefore it is suggested that rmr' should be used when gsi $>35$ for weak rock mass gsi should be directly using gsi chart. Here in this case gsi value directly obtained using gsi chart. These values assigned for various litho units obtained from ea- 08 given in Table 4 \& Figure 9. Based on above assigned/recommended ucs and gsi values further roclab software is used to estimate the geotechnical parameters in design analysis for different litho- units as shown in Figure 10.

\section{Support recommendations}

Detail design analysis has been carried out to finalize the support system on trt outfall slope using global and local stability in dry, wet and saturated ground water conditions (Table 5) summarized 
the support recommendations for outfall slope. ${ }^{9,10}$ It has also been recommended that all the activities for stabilization of slope to be carried out from top to bottom elevation with proper monitoring.

E. Methodology adopted for the stabilization

Keeping view of support recommendations after conducting detailed analysis, a methodology with sequence wise excavation and support details prepared to stabilize the out fall slope. As stated above all the excavation and stabilization work carried out from top elevation. Top bench elevation varying from el:-670.0 to $660.0 \mathrm{~m}$.the support system for this bench is reinforced cladding wall with berm

Table 2 Showing the details of Core Hole executed at different locations of TRT outfall

\begin{tabular}{|c|c|c|c|c|c|c|c|c|}
\hline SI. No. & $\begin{array}{l}\text { Name } \\
\text { of Hole }\end{array}$ & RD/Location & $\begin{array}{l}\text { Size of Hole } \\
(\mathrm{mm})\end{array}$ & $\begin{array}{l}\text { Length of } \\
\text { Hole }\end{array}$ & $\begin{array}{l}\text { Angle with } \\
\text { Horiz. }\end{array}$ & $\begin{array}{l}\text { Start Date of } \\
\text { Bore hole }\end{array}$ & $\begin{array}{l}\text { Finish Date } \\
\text { of Boring }\end{array}$ & Remarks \\
\hline I & $\mathrm{CH} 57$ & TRT-3 Outlet & $76(\mathrm{Nx})$ & 34 & 90 & |3-Oct-II & I8-Oct-II & \\
\hline 2 & $\mathrm{CH} 58$ & TRT-4 Outlet & $76(\mathrm{Nx})$ & 34 & 90 & |9-Oct-II & $25-O c t-1 I$ & \\
\hline 3 & $\mathrm{CHPI}$ & & $76(\mathrm{Nx})$ & 37.2 & 90 & $20-A p r-15$ & 30-Apr-I5 & \\
\hline 4 & $\mathrm{CH}$ P2 & TRT Outlet & $76(\mathrm{Nx})$ & 30.2 & 65 & 18-May-I5 & 2-Jun-15 & \\
\hline 5 & $\mathrm{CH}$ P3 & & $76(\mathrm{Nx})$ & 55 & 0 & 9-Jun-15 & 27-Jun-15 & \\
\hline 6 & CH P3' & & $76(\mathrm{Nx})$ & 20 & 90 & 12-Apr-15 & 18-Apr-15 & \\
\hline
\end{tabular}

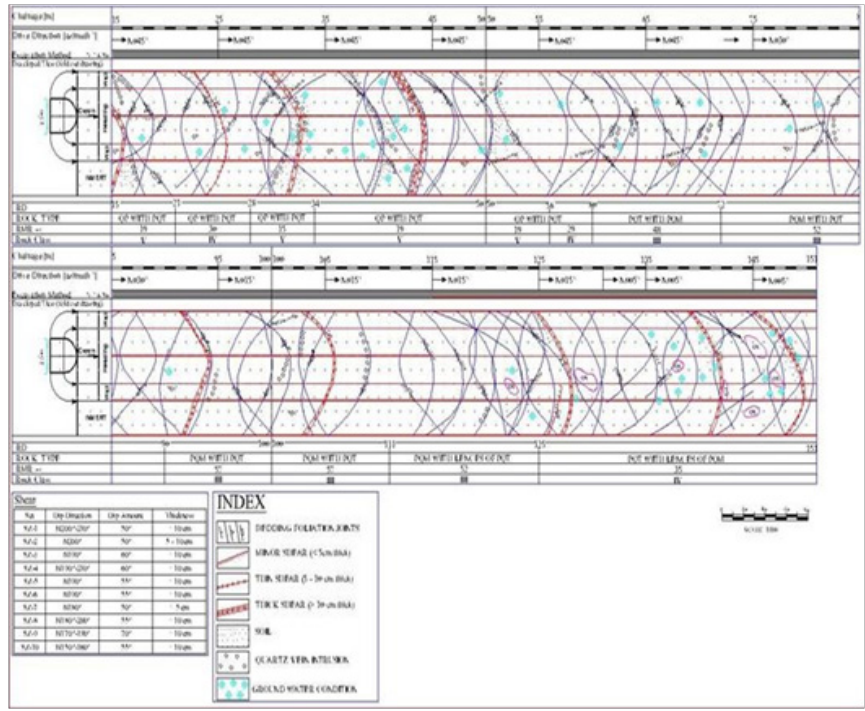

Figure 7 Three Dimensional Geological mapping representing rock type and trends of joints/Shears

Table 3 Assigned UCSValues for different Litho-units

\begin{tabular}{lll}
\hline Rock Type & $\begin{array}{l}\text { Average UCS } \\
\text { Value(MPA) }\end{array}$ & $\begin{array}{l}\text { Assigned UCS } \\
\text { Value(MPA) }\end{array}$ \\
\hline SP & 23 & 23 \\
PQT+PQM & 53 & 53 \\
QP+PQT & 45 & 45 \\
\hline
\end{tabular}

at el:-660.0m along with rock anchors of $25 \mathrm{~mm}$ diameter, $6.0 \mathrm{~m}$ long cement grouted @ spacing of $2.0 \mathrm{~m} \mathrm{c} / \mathrm{c}$. Drainage holes of $76 \mathrm{~mm}$ diameter,6.0m long@4.0m c/c spacing with perforated pvc pipe. To ensure that rock anchors and cladding wall work as a composite system, the bearing plate on rock anchors are placed over cladding wall. ${ }^{10}$ The cladding wall is provided to strengthen the existing road level@el:-670.0m. After completion of cladding wall, excavation and support installation work below el:-660.0m will be started. The bench wise sequence and support system is mentioned in tabular form (Table 6) (Table 7).

Table 4 Assigned UCS Values for different Litho- units

\begin{tabular}{lll}
\hline Rock Type & GSI Range & GSI Assigned \\
\hline SP & $20-30$ & 25 \\
PQT+PQM & $40-50$ & 45 \\
QP+PQT & $30-40$ & 35 \\
\hline
\end{tabular}

Table 5 Summarized the support recommendations.

\begin{tabular}{|c|c|c|}
\hline $\begin{array}{l}\text { Sl. } \\
\text { No. }\end{array}$ & Activity & Support Details \\
\hline 1 & Slope Excavation & $\begin{array}{l}\text { The cut slope above El:- } 616.0 m \text { to be } \\
\text { excavated in } I(H): 2(H) \text { slope while below } \\
\text { that } I(H): 5(H) \text { in slope }\end{array}$ \\
\hline \multirow[t]{2}{*}{2} & $\begin{array}{l}\text { Rock bolts and Cable } \\
\text { anchors at main cut } \\
\text { slope face }\end{array}$ & $\begin{array}{l}8 \text { rows of I } 20 \text { Ton cable anchors @ } 2.0 \\
\text { X } 2.0 \mathrm{~m} \text { c/c spacing (staggered) above El:- } \\
608.0 \mathrm{~m} \text { to be provided(Figure:- I I) }\end{array}$ \\
\hline & & $\begin{array}{l}\text { Apart from this pre tensioned fully } \\
\text { grouted rock bolts of } 310 \mathrm{KN}, 12.0 \mathrm{~m} \text { in } \\
\text { length@ } 1.5 \times 1.5 \mathrm{~m} \text { c/c shall be provided }\end{array}$ \\
\hline 3 & $\begin{array}{l}\text { Rock bolts at Upstream } \\
\text { and Downstream cut } \\
\text { slope faces }\end{array}$ & $\begin{array}{l}\text { Pre tensioned fully grouted rock bolts of } \\
310 \mathrm{KN}, 12 \mathrm{~m} \text { in length @ } 1.5 \times 1.5 \mathrm{~m} \mathrm{c} / \mathrm{c} \\
\text { spacing shall be provided }\end{array}$ \\
\hline 4 & $\begin{array}{l}\text { Shotcrete at all slope } \\
\text { faces }\end{array}$ & $\begin{array}{l}100 \mathrm{~mm} \text { thick layer of shotcrete with } \\
\text { one layer }\end{array}$ \\
\hline & & of wire mesh shall be provided \\
\hline 5 & Drainage System & $\begin{array}{l}\text { Drainage holes of } 76 \mathrm{~mm} \text { diameter, } \\
10.0 \mathrm{~m} \text { long @ } 3.0 \mathrm{~m} \mathrm{c} / \mathrm{c} \text { (staggered) shall } \\
\text { be provided in upward } 20^{\circ} \text { direction to } \\
\text { avoid the saturation of rock mass }\end{array}$ \\
\hline 6 & Monitoring of Slope & $\begin{array}{l}\text { Proper monitoring of slope is required } \\
\text { during and after construction }\end{array}$ \\
\hline
\end{tabular}

Citation: Sharma N, Prasad R. Geological and Geotechnical Evaluation for the Stabilization of Tail Race Tunnel Outfall Slope - A case study of Tehri Pump Storage Plant (I000 MW), Tehri Garhwal (Uttarakhand). Fluid Mech Res Int J. 20I8;2(5):234-24I. DOI: I0.15406/fmrij.20I8.02.00043 

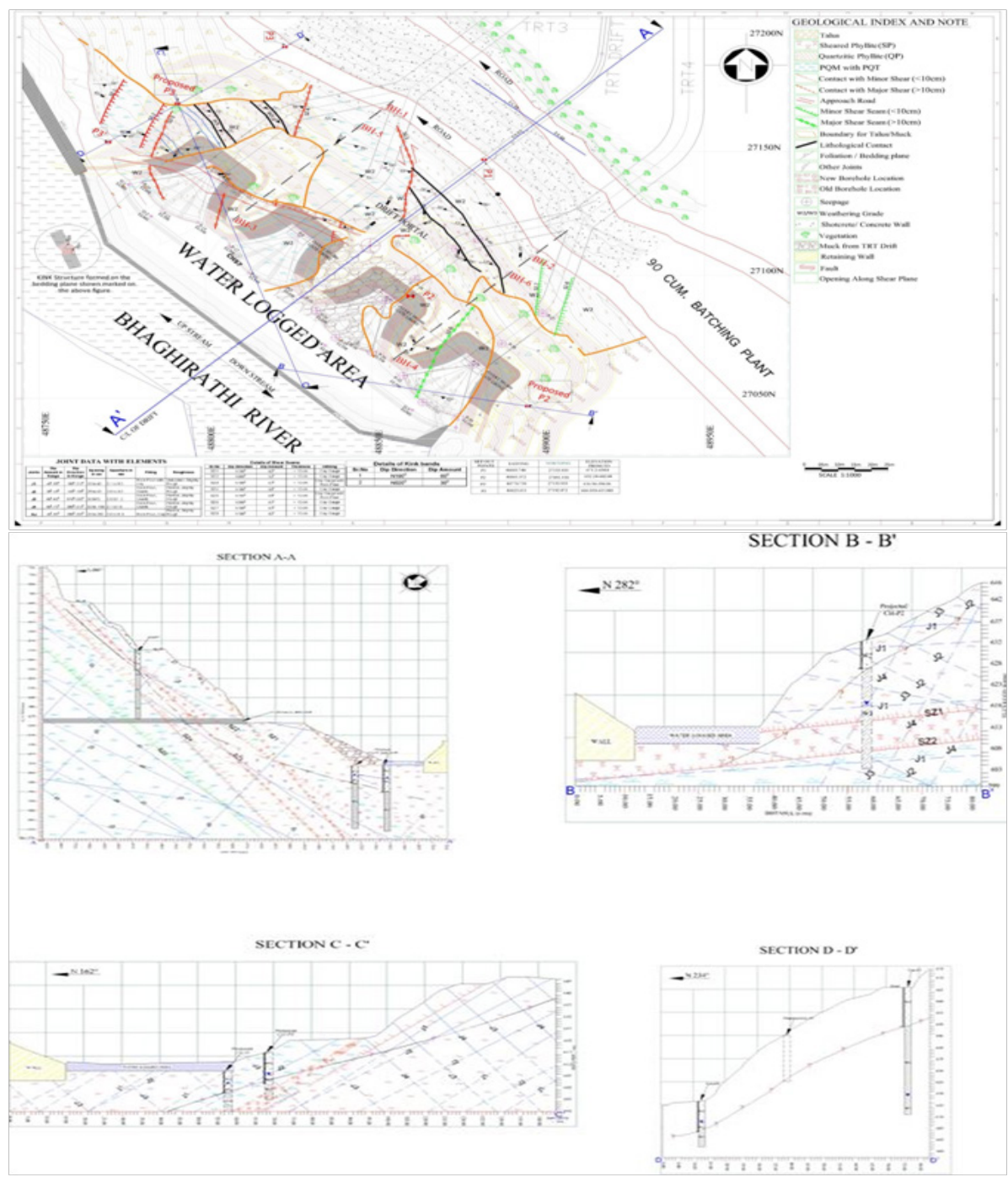

Figure 8 Geological Plan \& Sections of TRT Out-Fall Area

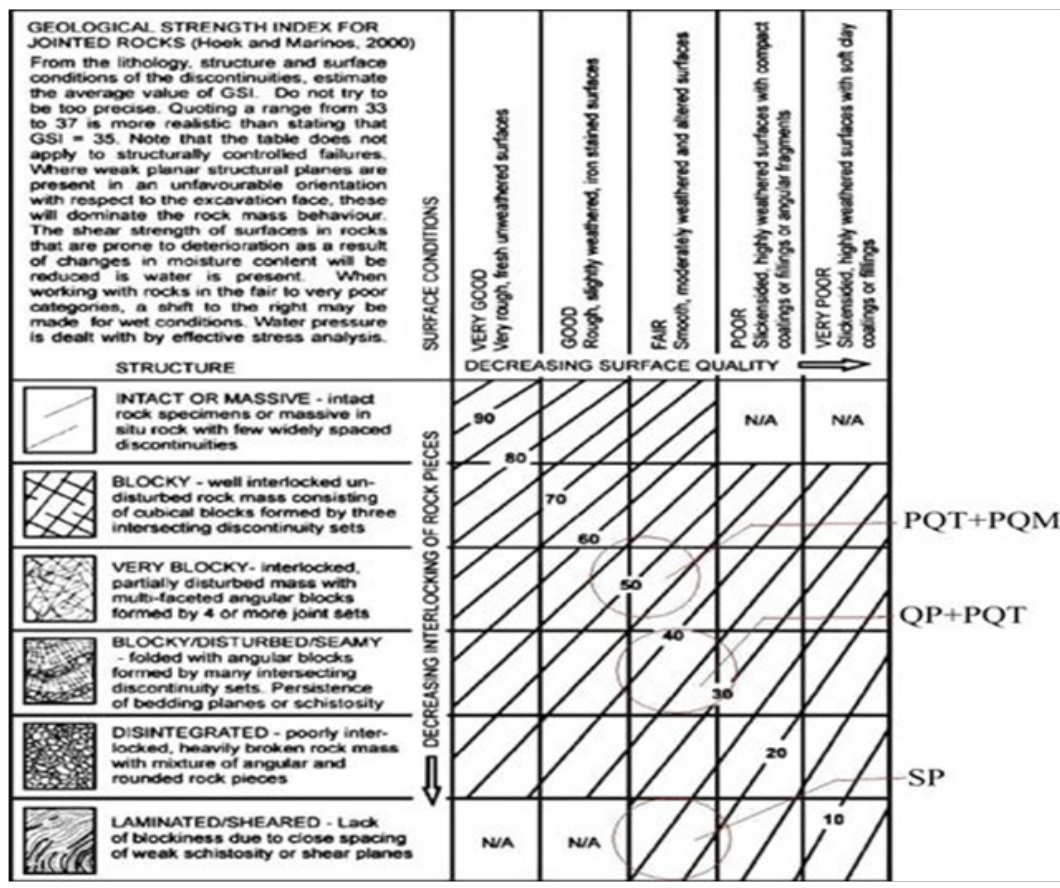

Figure 9 Geological Strength Index for different litho-units along EA-08(After Marinos \& Hoek 2000)

Citation: Sharma N, Prasad R. Geological and Geotechnical Evaluation for the Stabilization of Tail Race Tunnel Outfall Slope -A case study of Tehri Pump Storage Plant (I000 MW), Tehri Garhwal (Uttarakhand). Fluid Mech Res Int J. 20I8;2(5):234-24I. DOI: I0.15406/fmrii.2018.02.00043 


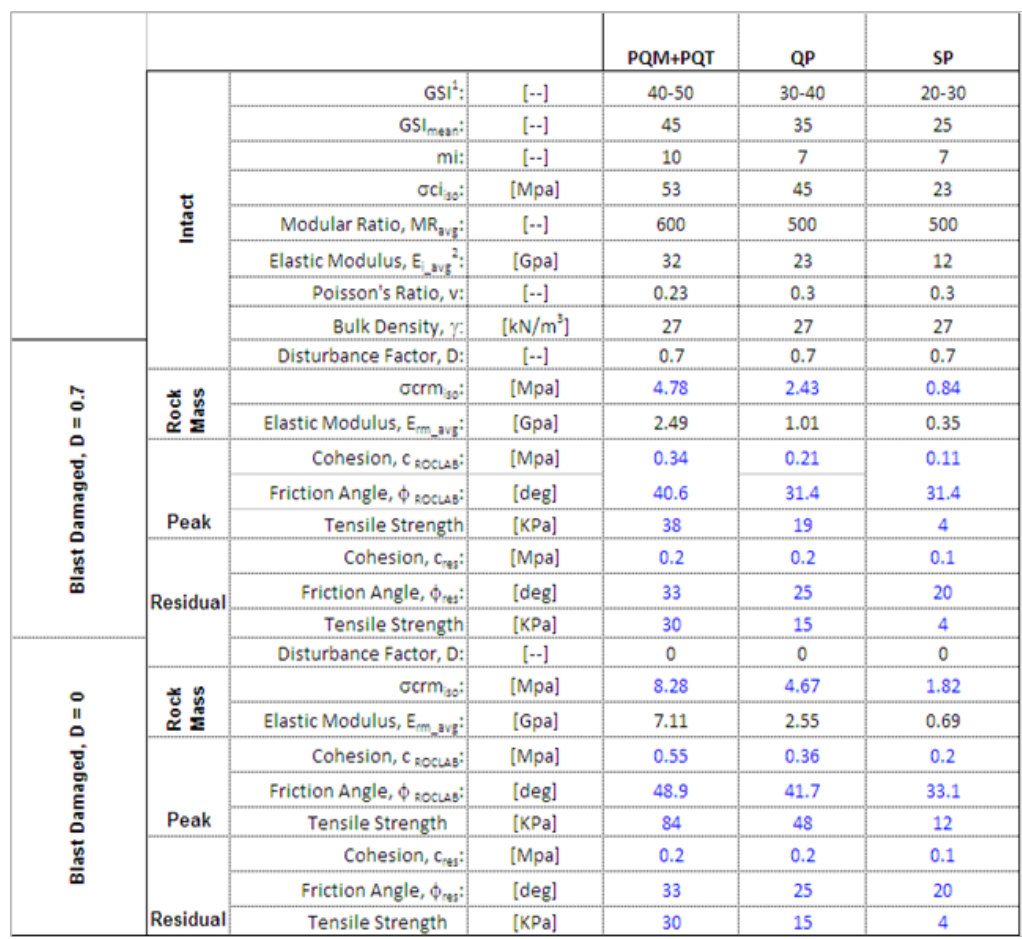

Figure 10 Geotechnical Parameters obtained from ROCLAB software

Table 6 Slope supports at face corresponding to Bench Elevation

\begin{tabular}{|c|c|c|c|c|c|c|c|}
\hline \multicolumn{8}{|c|}{ Slope Support at Face } \\
\hline Elevation & & Shotcrete & Wire Mesh & Rock Bolts & & Drainage Holes & Cable Anchors \\
\hline From & To & & & Type & Length & & \\
\hline 660 & 644 & \multirow{5}{*}{$100 \mathrm{~mm}$} & \multirow{5}{*}{ I layer } & \multirow{5}{*}{$\begin{array}{l}350 \mathrm{KN}, 32 \varnothing \\
\text { Pretensioned } \\
\text { grouted rock } \\
\text { bolts }\end{array}$} & \multirow{5}{*}{$12.0 \mathrm{~m}$} & \multirow{5}{*}{$\begin{array}{l}76 \varnothing, 10.0 \mathrm{~m} \text { long, } \\
\text { inclination } 20^{\circ} \\
\text { upward }\end{array}$} & \multirow{5}{*}{$\begin{array}{l}\text { El:- } 624.0 \text { to } \\
610.0 \mathrm{~m}, 20.0 \mathrm{~m} \\
\text { long }, 10^{\circ} \\
\text { downward with } \\
120 \text { Ton capacity }\end{array}$} \\
\hline 644 & 632 & & & & & & \\
\hline 632 & 616 & & & & & & \\
\hline 616 & 608 & & & & & & \\
\hline 608 & 598 & & & & & & \\
\hline
\end{tabular}

Table 7 Slope supports at End wall corresponding to Bench Elevation

\begin{tabular}{|c|c|c|c|c|c|c|}
\hline \multicolumn{7}{|c|}{ Slope Supports at End Walls } \\
\hline \multicolumn{2}{|l|}{ Elevation } & \multirow[t]{2}{*}{ Shotcrete } & \multirow[t]{2}{*}{ Wire Mesh } & \multicolumn{2}{|l|}{ Rock Bolts } & \multirow[t]{2}{*}{ Drainage Holes } \\
\hline From & To & & & Type & Length & \\
\hline 660 & 644 & & & \multirow{5}{*}{$\begin{array}{l}350 \mathrm{KN}, 32 \varnothing \\
\text { Pretensioned } \\
\text { grouted rock } \\
\text { bolts }\end{array}$} & \multirow{5}{*}{$8.0 \mathrm{~m}$} & \multirow{5}{*}{$\begin{array}{l}76 \varnothing, 10.0 \mathrm{~m} \text { long, } \\
\text { inclination } 20^{\circ} \text { upward }\end{array}$} \\
\hline 644 & 632 & & & & & \\
\hline 632 & 616 & $100 \mathrm{~mm}$ & I layer & & & \\
\hline 616 & 608 & & & & & \\
\hline 608 & 598 & & & & & \\
\hline
\end{tabular}

\section{Instrumentation}

The geotechnical instrumentation plays a vital role in evaluating the structural performance of an underground structure. The natural ground or rock mass tends to deform and de-stress when subjected to excavations, foundation and other loadings etc. Activities like squeezing, swelling and creeping depending upon the mechanical characteristics of the material are also responsible for the disturbances inside the rock mass. The long term performance of any structure is monitored by installing the structural instruments to predict and evaluate the safety of excavated openings. However, the question on number, type of instruments can only be addressed by fortuitous combination of understanding the structural behavior. ${ }^{11}$ Various type of instruments are recommended like multiple type bore hole extensometer (mpbx), optical targets and stand pipe piezometer at various level as mentioned below

i. Mpbx,4 points @el:- 644.00 and 616.00m,7 inclined downward to be installed 
ii. Optical targets in between el:-652.00 to $600.00 \mathrm{~m}$

iii. Standpipe piezometer @ el:-632.00 and 518.00m, if wet ground water conditions observed.

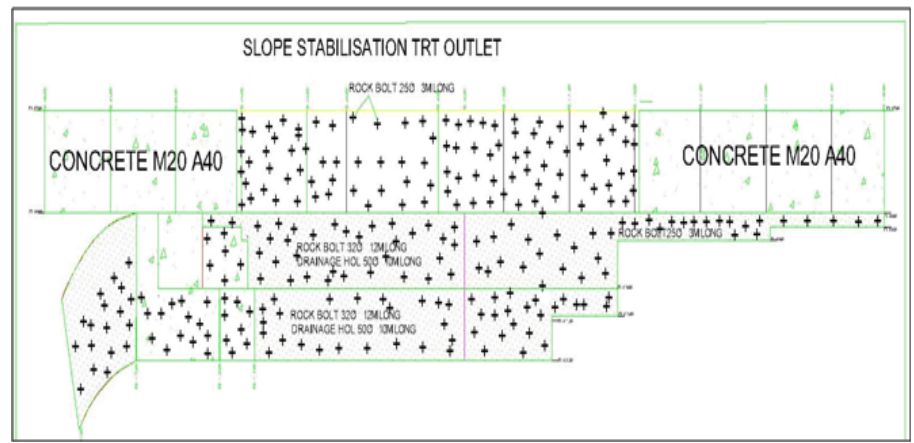

Figure I I Present Status of TRT outfall slope

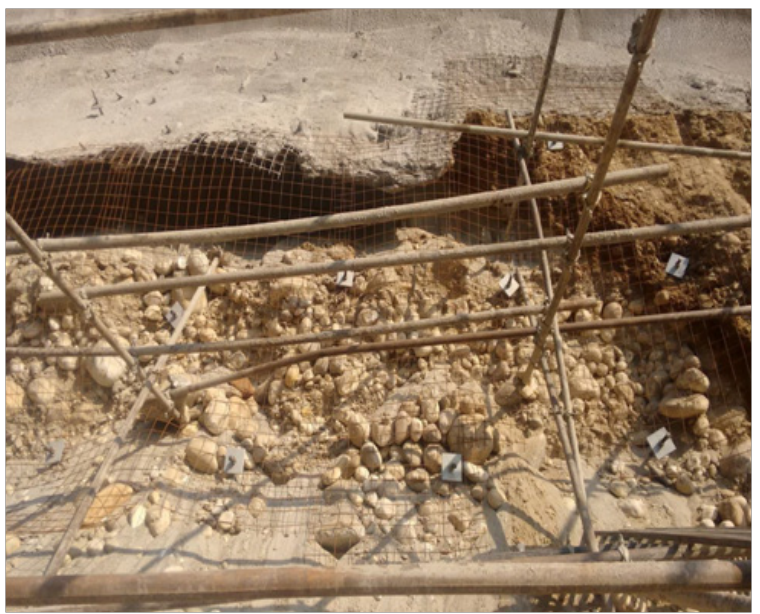

Figure I 2 View of RBM \& Talus/Filled Muck in TRT Outfall Area

Proper geotechnical monitoring with prescribed instruments

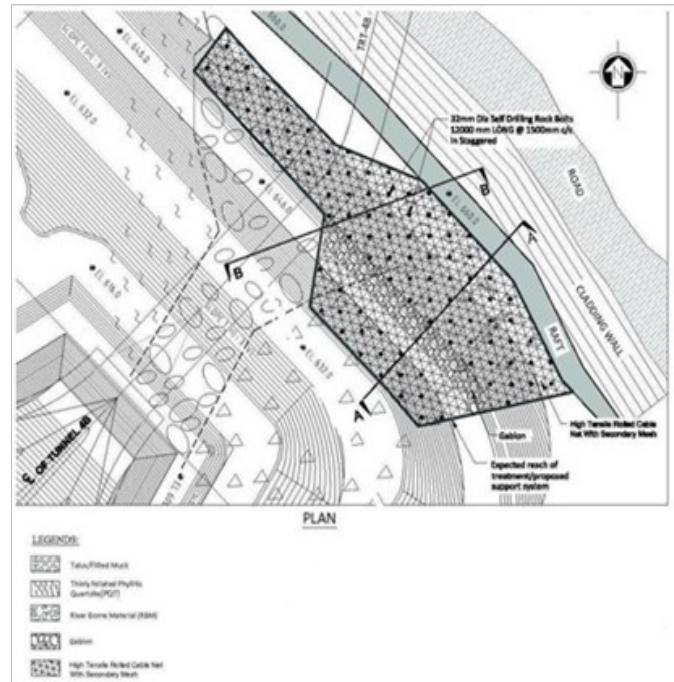

Figure 13 Geological Map \& Section of RBM \& Talus Muck in TRT Outfall Area

\section{Conclusion}

Selection of excavation methodology for the geological surprise area and design of support system is always a challenging. Following are the conclusions from the analysis for the recommendation during construction: carried out regularly and it has been observed that the deformation are

\section{A. Present status of trt outfall slope}

Excavation sequence and support system provided as per approved methodology with proper monitoring. Benches are properly monitored and geologically mapped to know the structural behavior of rock mass. Details of support system installed till date is shown in Figure 11. A geological surprise was encountered during excavation in the downstream area from el:-660.0 to $641.0 \mathrm{~m}$ where rbm (rive borne material) and talus/filled muck were observed. The thickness of this band is $\pm 60.0 \mathrm{~m}$. It was decided to protect this zone by single layer of wire fixed with soil nails along with $100 \mathrm{~mm}$ thick dry shotcrete (m25 a10). Self drill anchors (25ø), 3.0m in length with a spacing $1.5 \mathrm{~m} \mathrm{c} / \mathrm{c}$ has been provided. Till date support system provided up to el:- $\pm 652.0 \mathrm{~m}$ in rbm and el:- $\pm 634.0 \mathrm{~m}$ in rocky strata (Figure 12). On the basis of surface geological map two numbers of sections were developed to know the accuracy of rbm and talus deposit thickness (Figure 13). Designed methodology reviewed and support system recommended for this area is slightly changed high tensile rolled cable with secondary mesh along $32 \varnothing$ self drill anchor, $12.0 \mathrm{~m}$ in length to be provided. Instead of shotcrete, non woven geogreen erosion control blanket for plantation will be used in such type of exposure. ${ }^{12,13}$ The typical tensile strength is more than $7.5 \mathrm{kn} / \mathrm{m}$ in machine direction and $1.5 \mathrm{kn} / \mathrm{m}$ in cross direction the specified nominal weight of blanket is $600 \mathrm{gm} / \mathrm{sqm}$ and thickness is $6 \mathrm{~mm}$. Installation of self drill anchors was not smooth in rbm due to encounter of boulders and pebbles. Further excavation in $\mathrm{rbm}$ at el:-646.00m gabions were provided to support the toe. The high tensile cable net will also be anchored through the bottom of gabion walls. Slope is being cut in bench depth of 1:5 with application of simultaneously support system. The soil nails will also be used in excavation to hold the rbm behind the treated area while excavating below the treated portion of rbm for each bench. Excavation is in progress and support system shall be provided based on geological features and geotechnical monitoring. beyond warning limit.

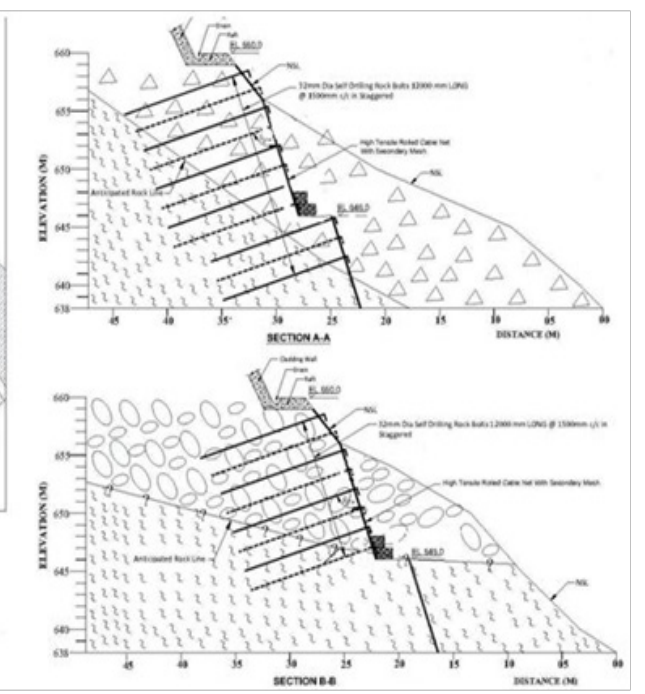

1. The global stability is more critical than the local stability.

2. The high strength cable anchors in main cut slope are exclusively designed to support the most critical failure mechanism, i.e. Polygonal failure along shear zones and planar failure with $\mathrm{j} 1 \mathrm{set}$ of joint.

3. The slope must be excavated top to bottom and not more than 2 
to $3 \mathrm{~m}$ benching at a time, after excavation of every bench/round, proposed support system must be installed and only than next bench/round should be excavated.

4. Proper drainage arrangement is of high importance, which is a very important factor for the stabilization of outfall slope during construction stage; the support assessment should be continuously reviewed based on actual geological features encountered at site and slope movement monitoring.

5. Geotechnical monitoring of the slope should start right from the start of excavation till the End and should be carried out after the completion of construction too.

6. It is very important that work of the project is executed safely without any accident at the time of Execution of work as well as during the operation of project. Generally slopes are treated as per the assessment of site conditions. So it's very important that design and drawing of slope excavation are reviewed time to time with the progress of excavation. The treatment done using geo green blanket is also environment friendly as it promotes the green vegetation /plantation.

\section{Acknowledgements}

Authors are thankful to the management of thdc india ltd. \& m/s. Hindustan construction co. Ltd. For providing necessary support to carry out the work.

\section{Conflicts of interest}

There is no conflict of interest between the authors.

\section{References}

1. Bieniawski ZT. Engineering Classification of jointed rock masses. Transactions of the South African Institution of Civil Engineers. $1973 ; 15: 335-344$
2. Bieniawski ZT. A Complete Manual for Engineers and Geologists in Mining, Civil and Petroleum Engineering. Engineering Rock Mass Classification. $1^{\text {st }}$ ed. New York: Wiley; 1989.

3. Gupta V, Sah MP, Virdi NS, et al. Landslide Hazard Zonation in the Upper Satluz Valley, District Kinnaur, Himachal Pradesh. Jour of Himalayan Geology. 1993;4(1):81-93.

4. Hoek E, Diederichs MS. Empirical estimation of Rock Mass Modulus. International Journal of Rock Mechanics and Mining Sciences. 2006;43(2):203-215.

5. Hoek E, Brown ET. Practical Estimates of Rock Mass Strength. International Journal of Rock Mechanics and Mining Science.1997;34(8):11651186.

6. Hoek E, Marinos V, Marinos P. GSI Applications and Limitations. 2005;64(1):55-65.

7. Hoek E. Practical Rock Engineering, Toronto. Rocscience. 2007.

8. Marinos V, Marinos P, Hoek E. The geological strength index. applications and limitations. 2005;64:55-65.

9. Siddique T, Pradhan SP, Vishal V, et al. Stability Assessment of Himalayan Road Cut Slopes along National Highway 58. India Enviro Earth. 2017;85(1):487-503.

10. Detailed Project Report of Tehri PSP, Unpublished report.

11. Hussain Gulzar, Singh Yudhbir, Bhat Ghulam Mohd. Geotechnical Investigation of Slope along NH-1D, Journal of Scientific Research. 2015;5(2):56-67.

12. Maurulanda, Camilo, Marulunda. Experience in Large Slope Stability under Complex eology. International Conference on Case Histories in Geotechnical Engineering-Seventh International Conference on case Histories in Geotechnical Engineering. 2013.

13. Preliminary Geotechnical Assessments of Effects. Prepared for TNZ Transport Agency. 2015. 